\title{
Genetic Diversity Analysis for Seed Yield and its Attributes in Fenugreek (Trigonella foenum-graecum $\mathrm{L}$.)
}

\author{
Jyoti Asati*, Pratik desai and R.K. Patel \\ Department of Genetics and Plant breeding, N.M.C.A, Navsari Agri. University, Navsari- \\ 396450 (Gujarat), India \\ *Corresponding author
}

\begin{tabular}{|l|}
\hline K e y w o r d s \\
D² statistic, \\
fenugreek, Genetic \\
divergence, Seed \\
spice, Quantitative \\
characters
\end{tabular}

Keywords

$\mathrm{D}^{2}$ statistic, fenugreek, Genetic divergence, Seed characters

Article Info

15 November 2018

10 December 2018

\section{A B S T R A C T}

Fourty genotypes of fenugreek were grown at College Farm, N. M. College of Agriculture, Navsari Agricultural University, Navsari during Rabi 2015-16. Grouping of the genotypes was carried-out by following Tocher's method (Rao, 1952). The $\mathrm{D}^{2}$ analysis indicated presence of ample genetic diversity among the genotypes studied, which were grouped into 6 clusters. The maximum inter-cluster distance was observed between cluster-VI and V followed by cluster-VI and V. The minimum inter-cluster distance was depicted between cluster-V and IV. The Intra cluster distance is 8.40 (cluster I), while remaining clusters had only one genotype. Therefore, the genotypes belonging to these clusters may be undertaken in a hybridization programme for getting better segregants. The analysis on contribution of various characters towards the expression of genetic divergence indicated that the characters viz., Total oil content, protein content, green biomass per plant, secondary branches per plant, days to $50 \%$ flowering, length of pod and primary branches per plant contributed maximum towards the total genetic divergence. Superior genotypes viz., NFG-33, NFG-28, NFG-38, NFG-14 and NFG-36 can be used in breeding programmes through either pureline or mass selection methods or hybridization for the development of superior fenugreek varieties for commercial cultivation.

\section{Introduction}

Fenugreek (Trigonella foenum-graecum L.) is an annual diploid species, popularly known by its vernacular name "methi" belonging to the sub-family "Papilionaceae" of the family "Fabaceae". It is native crop of the countries bordering the eastern shores of Mediterranean region and extended to central Asia. It is a self pollinated crop with somatic chromosome number of $2 n=16$ (Raghuvanshi and Singh,
1977). This crop is grown mainly for its leaves and seed.

The productivity of this crop is very low as this crop is often cultivated on marginal lands with poor management of soil fertility, irrigation, fertilizer and with little insect pest management. Further the seeds of improved varieties have limited availability. Considering the above points, there is a great scope to improve the productivity of this crop by 
varietal improvement and adopting the improved production technology in our country.

The multivariate analysis by means of Mahalanobis $\mathrm{D}^{2}$ statistic for estimating genetic divergence has been emphasized by many workers (Anand and Murty 1968; Arunachalam, 1981; Anand and Rawat, 1984). The more diverse the parents, within overall limits of fitness, the greater are the chances of obtaining higher amount of heterotic expression in F1 and broad spectrum of variability in segregating generations (Anand and Murty, 1968).

\section{Materials and Methods}

A set of fourty genotypes of fenugreek were evaluated for genetic divergence in the present investigation. The experiment was conducted in a Randomized Block Design (RBD) with three replications during the rabi season of Year 2015-16 at the College Farm, N. M. College of Agriculture, Navsari Agricultural University, Navsari. The data were recorded from five randomly selected plants for each genotypes in all the replications for fourteen characters, viz., plant height $(\mathrm{cm})$, primary branches per plant, secondary branches per plant, days to $50 \%$ flowering, days to maturity, seed yield (kg/ha), 1000 seed weight, pods per plant, grains per pod, pod length $(\mathrm{cm})$, harvest index, green biomass per plant $(\mathrm{g})$, seed protein $(\%)$ and total oil content (\%). Data were subjected to analysis of genetic divergence, following Mahalanobis D2 statistic (Mahalanobis, 1936) and genotypes were grouped following Tocher's method (Rao, 1952).

\section{Results and Discussion}

The analysis of variance pooled over the seasons showed significant difference among fourteen characters, viz., plant height $(\mathrm{cm})$, primary branches per plant, secondary branches per plant, days to $50 \%$ flowering, days to maturity, seed yield (kg/ha), 1000 seed weight, pods per plant, grains per pod, pod length $(\mathrm{cm})$, harvest index, green biomass per plant (g), seed protein (\%) and total oil content $(\%) . \mathrm{D}^{2}$ statistic was estimated on fourty genotypes for fenugreek revealed generalized distance (D) from 7.60 to 19.01 between two populations which pointed out the diversity present in material under evaluation.

Forty genotypes of fenugreek were grouped into six clusters according Tocher's method. The composition of clusters is given in Table 1. The results indicated that a maximum number of diverse genotypes (35 genotypes) appeared in cluster I. All other five clusters were composed by single genotype. The distribution pattern revealed that genotypes from different geographic regions were grouped in same cluster. Similarly, the genotypes from same geographic regions were scattered in different clusters. Hence, it could be concluded that there is no association between geographic diversity and genetic diversity.

Considerable higher intra and inter-cluster values revealed very interesting trend of genetic diversity. Intra-cluster $\mathrm{D}$ values of various clusters were found to be comparatively small indicating the presence of substantial genetic diversity even within the cluster. The maximum inter-cluster distance ( $\mathrm{D}=19.01)$ was observed between cluster-VI and $\mathrm{V}$ followed by those between cluster-VI and $\mathrm{V}(\mathrm{D}=17.10)$. The minimum inter-cluster distance $(\mathrm{D}=7.60)$ was depicted between cluster-V and IV. The results are in conformity with the report of Jain et al., (2006), Fikreselassie et al., (2012), Kole and Goswami (2015) and Wojo et al., (2015).

In heterosis breeding, genotypes of diverse clusters are known to play an important role of 
potential parents and when each genotypes of different cluster are inter crossed they are likely to produce heterotic combinations.

Total oil content, protein content, green biomass per plant, secondary branches per plant, days to $50 \%$ flowering, length of pod and primary branches per plant contributed maximum towards the total genetic divergence. These seven characters accounted for more than $90 \%$ of total divergence in the material studied.

Cluster mean for ten characters in fenugreek clearly indicate appreciable difference among cluster means for most of the characters. Greater range of mean values among the clusters was recorded for different traits. The cluster I revealed maximum values for seed yield(kg/ha) (796.56), 1000 seed weight(g) (26.93), grains per pod (13.43), pod length (11.85), and harvest index (29.45), the genotypes of cluster III revealed maximum values for secondary branches per plant (4.37) green biomass (36.50) and seed protein (20.27), the genotypes of cluster IV recorded highest values for plant height $(56.00 \mathrm{~cm})$ and pods per plant (39.67), The character total oil content recorded maximum mean value for the genotypes of cluster V (24.02) and same pattern followed by days to 50 percent flowering (51.00). Similar results are reported by Jain et al., (2006), Gangopadhyay et al., (2010), Fikreselassie et al., (2012), and Wojo et al., (2015).

The results showed that hybridization among genotypes of these cluster combinations is expected to enhanced variability. Apart from the high divergence, the performance of the genotypes and the characters with maximum contribution towards divergence should also be given due consideration which appears as desirable for inclusion for improvement in fenugreek (Fig. 1).

Table.1 The distribution of fourty genotypes of fenugreek into 6 different clusters on the basis of Mahalanobis $\mathrm{D}^{2}$ statistic

\begin{tabular}{|c|c|c|}
\hline Cluster & $\begin{array}{l}\text { Number of } \\
\text { genotypes }\end{array}$ & Name of genotypes \\
\hline I & 35 & $\begin{array}{l}\text { NFG-28, NFG-33, NFG-14, NFG-38, NFG-36, NFG- } \\
\text { 18, NFG-16, NFG-30, NFG-37, NFG-13, NFG-32, } \\
\text { NFG-15, NFG-4, NFG-29, NFG-34, NFG-11, NFG- } \\
\text { 35, NFG-23, NFG-19, NFG-8, NFG-7, NFG-40, NFG- } \\
\text { 3, NFG-27, NFG-10, NFG-24, NFG-2, NFG-22, NFG- } \\
\text { 20, NFG-25, NFG-39, NFG-26, NFG-6, NFG-17, } \\
\text { NFG-5 }\end{array}$ \\
\hline II & 1 & NFG-1 \\
\hline III & 1 & NFG-9 \\
\hline IV & 1 & NFG-12 \\
\hline $\mathbf{V}$ & 1 & NFG-21 \\
\hline VI & 1 & NFG-31 \\
\hline
\end{tabular}


Table.2 Average Intra and Inter - cluster $\left(D^{2}\right)$ value for 40 genotypes of fenugreek

\begin{tabular}{|l|l|l|l|l|l|l|}
\hline Cluster & I & II & III & IV & V & VI \\
\hline I & 8.40 & 10.86 & 12.62 & 12.90 & 15.79 & 13.37 \\
\hline II & & 0.00 & 9.38 & 7.87 & 7.94 & 13.77 \\
\hline III & & & 0.00 & 15.27 & 7.60 & 17.10 \\
\hline IV & & & & 0.00 & 13.58 & 15.44 \\
\hline V & & & & & 0.00 & 19.01 \\
\hline VI & & & & & & 0.00 \\
\hline
\end{tabular}

Table.3 Contribution of fourteen characters under study to total divergence

\begin{tabular}{|l|l|l|}
\hline Characters & No. of times ranked first & $\begin{array}{l}\text { \% contribution towards } \\
\text { divergence }\end{array}$ \\
\hline Plant height $(\mathrm{cm})$ & 1 & 0.13 \\
\hline $\begin{array}{l}\text { Primary branches per plant } \\
\text { Secondary branches per } \\
\text { plant }\end{array}$ & 20 & 2.56 \\
\hline Days to 50\% flowering & 49 & 6.28 \\
\hline Days to maturity & 35 & 4.49 \\
\hline Seed yield (kg/ha) & 16 & 2.18 \\
\hline 1000 seed weight (g) & 0 & 2.05 \\
\hline Pods per plant & 4 & 0.00 \\
\hline Grains per pod & 0 & 0.51 \\
\hline Length of pod (cm) & 35 & 0.00 \\
\hline Harvest Index (\%) & 3 & 4.49 \\
\hline Green biomass per plant $(\mathrm{g})$ & 54 & 0.38 \\
\hline Seed protein $(\%)$ & 253 & 6.92 \\
\hline Total oil content $(\%)$ & 293 & 32.44 \\
\hline
\end{tabular}

Table.4 Analysis of variance for fourteen different traits of fenugreek

\begin{tabular}{|l|l|l|l|l|l|l|l|}
\hline $\begin{array}{l}\text { Cluster } \\
\text { Number }\end{array}$ & $\begin{array}{l}\text { Plant } \\
\text { height } \\
(\mathrm{cm})\end{array}$ & $\begin{array}{l}\text { Primary } \\
\text { Branches } \\
\text { per plant }\end{array}$ & $\begin{array}{l}\text { Secondary } \\
\text { branches } \\
\text { per plant }\end{array}$ & $\begin{array}{l}\text { Days to } \\
50 \% \\
\text { flowering }\end{array}$ & $\begin{array}{l}\text { Days to } \\
\text { maturity }\end{array}$ & $\begin{array}{l}\text { Seed } \\
\text { yield } \\
(\mathrm{kg} / \mathrm{ha})\end{array}$ & $\begin{array}{l}1000 \text { seed } \\
\text { weight }(\mathrm{g})\end{array}$ \\
\hline I & 49.21 & 2.73 & 3.11 & 43.89 & 97.47 & 796.56 & 26.93 \\
\hline II & 52.87 & 3.63 & 1.26 & 41.00 & 89.67 & 547.70 & 22.17 \\
\hline III & 45.50 & 2.80 & 4.37 & 44.00 & 98.33 & 581.00 & 25.17 \\
\hline IV & 56.00 & 3.13 & 2.07 & 46.67 & 100.00 & 619.18 & 24.02 \\
\hline V & 50.13 & 2.73 & 2.13 & 40.00 & 93.00 & 499.48 & 26.00 \\
\hline VI & 55.00 & 4.00 & 2.00 & 51.00 & 105.33 & 466.55 & 12.50 \\
\hline
\end{tabular}


Table.4 Continued

\begin{tabular}{|l|l|l|l|l|l|l|l|}
\hline $\begin{array}{l}\text { Cluster } \\
\text { Number }\end{array}$ & $\begin{array}{l}\text { Pods } \\
\text { per plant }\end{array}$ & $\begin{array}{l}\text { Grains } \\
\text { per pod }\end{array}$ & $\begin{array}{l}\text { Length } \\
\text { of pod } \\
(\mathrm{cm})\end{array}$ & $\begin{array}{l}\text { Harvest } \\
\text { Index } \\
(\%)\end{array}$ & $\begin{array}{l}\text { Green } \\
\text { biomass per } \\
\text { plant }(\mathrm{g})\end{array}$ & $\begin{array}{l}\text { Seed } \\
\text { protein } \\
(\%)\end{array}$ & $\begin{array}{l}\text { Total oil } \\
\text { content } \\
(\%)\end{array}$ \\
\hline I & 25.17 & 13.43 & 11.85 & 29.45 & 26.39 & 19.88 & 10.78 \\
\hline II & 20.40 & 11.62 & 10.40 & 20.37 & 26.17 & 14.76 & 16.43 \\
\hline III & 22.50 & 12.67 & 10.87 & 19.23 & 36.50 & 20.27 & 22.05 \\
\hline IV & 14.20 & 12.83 & 10.50 & 21.51 & 18.08 & 8.86 & 12.09 \\
\hline V & 17.27 & 11.80 & 10.77 & 20.09 & 21.33 & 15.34 & 24.02 \\
\hline VI & 39.67 & 5.87 & 1.63 & 18.13 & 16.33 & 20.13 & 9.10 \\
\hline
\end{tabular}

Figure.1 Dendorgram of 40 fenugreek genotypes based on fourteen traits

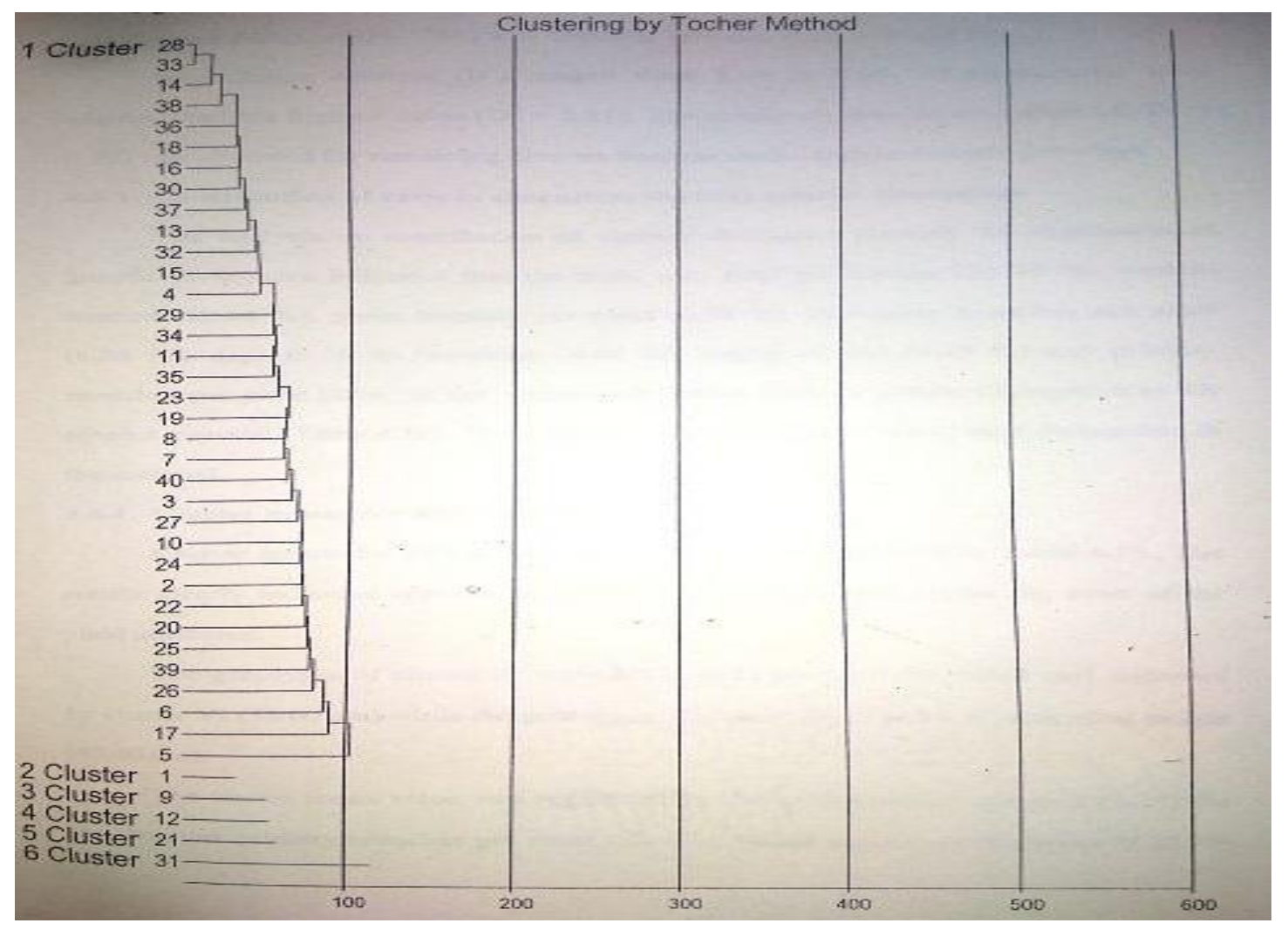

It could be concluded that high yielding genotypes coupled with other desirable traits like seed yield, 1000 seed weight, grains per pod, harvest index, pods per plant, pod length, and green biomass per plant, seed protein could be selected as parents for hybridization programme from cluster I, III, IV. Intercrossing genotypes from these clusters might result in wide array of variability for exercising effective selection. From the present investigation, the genotypes NFG-33, NFG-28, NFG-14, NFG-38, and NFG-36 were found to be superior with respect to yield and majority of the yield components coupled with good pod quality traits which can be used as parents in future breeding programmes following direct selection. 
In conclusion, the present investigation indicated that there is wide range of genetic variability and diversity in fenugreek germplasms. There is large scope of simultaneous improvement in seed yield through selection. Hybridization among germplasms from different clusters identified in this study could lead to considerable genetic improvement by following appropriate selection strategies in the segregating generations.

\section{References}

Anand, I.J. and Murty, B.R. (1968). Genetic divergence and hybrid performance in linseed. Indian Journal of Genetics \& Plant Breeding, 28:178-185.

Anand, I.J. and Rawat, D.S. (1984). Genetic diversity, combining ability and heterosis in brown mustard. Indian Journal of Genetics \& Plant Breeding, 44:226-234.

Arunachalam, V. (1981). Genetic distance in plant breeding. Indian Journal of Genetics \& Plant Breeding, 41:226236.

Fikreselassie, M., Zeleke, H. and Alemayehu, N. (2012). Genetic variability of Ethiopian fenugreek (Trigonella foenum-graecum L.) landraces. Journal of Plant Breeding and Crop Science, 4(3): 39-48.

Gangopadhyay, K. K., Yadav, S. K., Kumar, G., Meena, B. L., Mahajan, R. K., Mishra, S. K. and Sharma, S. K. (2009). Correlation, path coefficient and genetic diversity pattern in fenugreek (Trigonella foenumgraecum L.). Indian Journal Agricultural Sciences, 79(7): 521-526.

Jain, U. K., Singh, O., Balai, O. P. and Shiva, K. N. (2006). Genetic divergence in fenugreek (Trigonella foenumgraecum L.) germplasm. Journal of Spices and Aromatic Crops, 15(1): 5962.

Kole, P. C. and Goswami, T. (2015). Genetic divergence in fenugreek grown under sub-humid subtropical red lateritic belt of eastern India. International Journal of Bio-Resource, Environment and Agricultural Sciences, 1(3): 97-100.

Mahalanobis, P. C. (1928). On the generalized distance in statistics. Proceedings of the National Academy of Science, 19: 201-208.

Raghuvanshi, S. S. and Singh, A. K. (1977). Polyploid breeding in Trigonella foenum-graecum L. Cytologia, 42: 519.

Rao, C. R. (1952). Advanced Statistical methods in Biometrical Research. John Wiley and Sons, New York: 357369.

Wojo, A. A., Alamerew, S., Nebiyu, A. and Menamo, T. (2015). Cluster analyses based on yield and yield components in fenugreek (Trigonella foenumgraecum L.) Accessions. Global Journal of Science Frontier Research: $D$ Agriculture and Veterinar, 15(8): 57-63.

\section{How to cite this article:}

Jyoti Asati, Pratik desai and Patel, R.K. 2018. Genetic Diversity Analysis for Seed Yield and its Attributes in Fenugreek (Trigonella foenum-graecum L.). Int.J.Curr.Microbiol.App.Sci. 7(12): 1988-1993. doi: https://doi.org/10.20546/ijcmas.2018.712.229 